\title{
Mediating Role of Work Engagement in The Relationship between Human Resource Practices and Employee Competence in Nigerian Basic Education System: Building A Conceptual Framework
}

Isah Sani, Rashidah Binti Mohammad Ibrahim

To Link this Article: http://dx.doi.org/10.6007/IJARBSS/v10-i12/8088

DOI:10.6007/IJARBSS/v10-i12/8088

Received: 20 October 2020, Revised: 16 November 2020, Accepted: 07 December 2020

Published Online: 21 December 2020

In-Text Citation: (Sani \& Ibrahim, 2020)

To Cite this Article: Sani, I., \& Ibrahim, R. B. M. (2020). Mediating Role of Work Engagement in The Relationship between Human Resource Practices and Employee Competence in Nigerian Basic Education System: Building A Conceptual Framework. International Journal of Academic Research in Business and Social Sciences, 10(12), 247-263.

Copyright: @ 2020 The Author(s)

Published by Human Resource Management Academic Research Society (www.hrmars.com) This article is published under the Creative Commons Attribution (CC BY 4.0) license. Anyone may reproduce, distribute, translate and create derivative works of this article (for both commercial and non-commercial purposes), subject to full attribution to the original publication and authors. The full terms of this license may be seen

at: http://creativecommons.org/licences/by/4.0/legalcode

Vol. 10, No. 12, 2020, Pg. 247 - 263

Full Terms \& Conditions of access and use can be found at http://hrmars.com/index.php/pages/detail/publication-ethics 


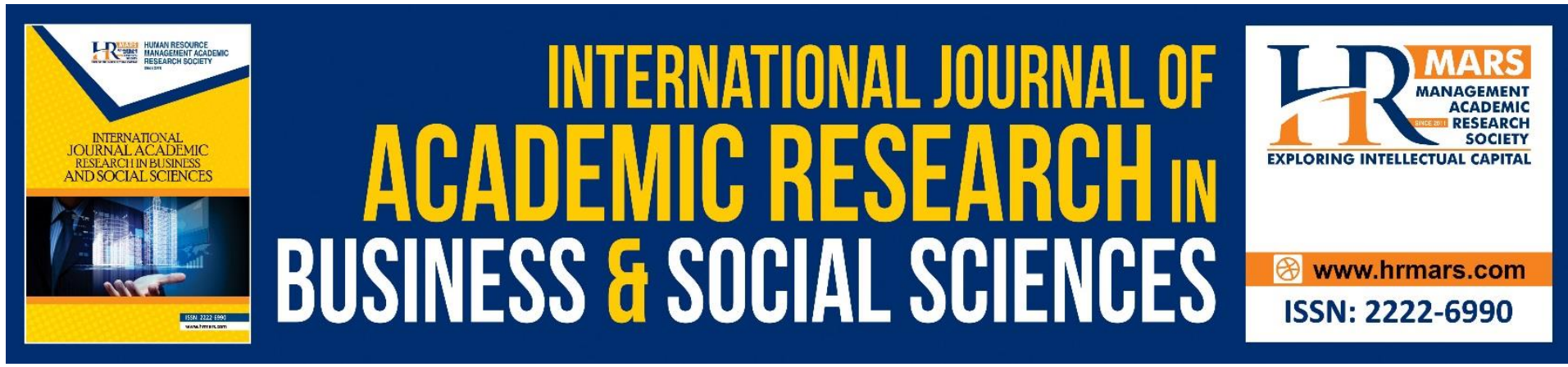

\title{
Mediating Role of Work Engagement in The Relationship between Human Resource Practices and Employee Competence in Nigerian Basic Education System: Building A Conceptual Framework
}

\author{
Isah Sani ${ }^{1,2}$, Dr. Rashidah Binti Mohammad Ibrahim² \\ ${ }^{1}$ Department of Public Administration, Faculty of Business and Administration, Waziri Umaru \\ Federal Polytechnic, Birnin-Kebbi, Kebbi State, Nigeria, ${ }^{2}$ Faculty of Business and \\ Management Universiti Sultan Zainal Abidin Terengganu, Malaysia.
}

Email: isahsaniwufed@gmail.com

\begin{abstract}
Competence is defined as the combination of related job skills, attitude, explicit and tacit knowledge that provides individuals the potential to perform their responsibilities effectively. Wide-ranging researches have confirmed the significant effect of employee competency in achieving organizational goals. In fact, enhancing employee's competence in organizations has always been the fundamental reason for adopting human resource practices in the quest for improve efficiency and effectiveness in service delivery. This paper is a conceptual one that aimed at proposing a conceptual framework and establish a link between human resource practices and employee competence. Within this framework, the paper will conceptually propose the possibility of work engagement to mediate in this relationship. Based on this, the paper will develop a research model and suggest propositions that will later be empirically tested within the context of Nigeria Basic Education system.
\end{abstract}

Keywords: Human Resource Practices, Work Engagement, Employee Competence, Basic Education System, Nigeria.

\section{Introduction}

The main competitive benefit of modern organizations is efficient, effective and competent employees who possess the necessary skills, knowledge and abilities in fulfilling their assigned responsibilities towards ensuring the achievement of organizational goals (Sargit et al., 2012). Considering the dramatic change in the social organizational environment as well as increase in modern competitive field, several organizations tends to teach, attract, save and more importantly improve individual's competence in order to achieve their present and future progressions. Therefore, employees remain as the parameter for organizational growth and sustainability (Rastgoo, 2016; Seema, 2016). The global competition demands for employees who are more flexible and acquired more skills and knowledge with abilities in discharging their responsibilities towards insuring the attainment of organizational objectives (Mahmood 
et al., 2016). Stakeholders in various organizations as well as policy makers have placed much priority on employees working in organizations by considering them as the key source of prosperity. Several studies were carried out with the aim of discovering factors that enhance employee competence and improve organizational performance. It has been suggested that, achievement of organizational objectives ultimately depends on its employees' competence (Rossilah, 2008). Researches from different fields such like human resource management, marketing, strategic management, information system, operational management has examined different kinds of variables which includes leadership styles, human resource practices, total quality management among others may enhance employee competence and improve organizational performance towards achieving success (Al-Ansari et al., 2014; Lo \& Fu, 2016; Wang et al., 2016).

For over decades, improving employee competence towards improved organizational performance has been the major issue of management research, public administration and policy studies (Al-Dhaafri et al., 2016; Darwish et al., 2018). Governments all over the world are searching for the best ways of enhancing competencies towards improving efficiency in their performance in terms of policy/programs outcomes, citizen's satisfaction, use of public resources, preventing corruption as well as enhancing accountability (Armstrong, 2005). Certainly, increasing employee competence in public sector towards ensuring ultimate performance has become very essential. Numerous public sector organizations place much emphasis on increasing employee competence in order to ensure transparency in utilizing public resources and public decisions towards better performance (Speklé \& Verbeeten, 2014). It has been revealed that, Nigerian public sector organizations are characterized by high level of unethical conduct leading to low level performance in most of the organization especially in the public educational sector which attract much concern from the general public (Inyang \& Akaegbu, 2014).

In the past few decades, the Universal Basic Education program was introduced in Nigeria with ultimate goal of providing free and compulsory basic education to all Nigerian children aged 6-15 years (Claudia, 2017). Other objectives include catering for the learning needs for young persons in the country, drastically reducing the rate of school drop-out through improved quality and efficiency, ensuring the attainment of appropriate level of numeracy, literacy, life skills, communication and manipulative skills (Claudia, 2017). The government in its efforts established an organization known as the Universal Basic Education Commission (UBEC) at the federal level, the state Universal Basic Education Boards (SUBEBs) across the 36 states of the geopolitical zones of the country, and the Local Government Education Authorities (LGEA) at districts level (UBE Act,2004, 2004). Despite all these efforts made by the government, still the rate of out-of-school children remains very high in the country.

Though, it has been observed that organizations that happens to be more successful in modern economy are increasingly understanding that there are quite a number of factors that tend to contribute to employee competence in an organization and human resource management practices said to be the most critical (Mello, 2005). The core idea of this study is to embark on empirical investigation on the mediating role of work engagement in the relationship between human resource management practices and employee competence within the context of Nigerian Universal Basic Education system. 


\section{Problem Statement}

Increasing number of out-of-school children in Nigeria is an alarming problem worthy of consideration. The level at which children attend school remains very low in most of the SubSahara African countries and other developing countries in the world (World Bank, 2014).This has led to the increasing global number of out-of-school children with about 262 million population comprising of children, adolescent and youth between the ages of 6 to 17 years' old who are out-of-school (SDG, 2018). In recent times, it has been reported that Nigeria has the highest number of out-of-school children in the world with a total number of 10.5 million children who are out-of-school (UNICEF, 2018). This situation has led to high level of illiteracy in the country with a recent report which shows that, out of estimated number of 170 million people in Nigeria, 75 million have not acquired the basic literacy skills (Jennifer, 2018), with about 33.5 percent increasing rate of unemployment, leading to high rate of poverty in the Nigeria (Ngige, 2020).

Consequently, a growing concern have been raised about the existence of unethical behaviors in the public education system administration in Nigeria. In fact, it has exposed and generated several numbers of scandal, corruption and inefficient service delivery in the system (Aminu, 2015; Buhari, 2015; Nasiru, 2015). It has been revealed that corruption has been the major impediment to the implementation of UBE program in Nigeria (Anthony, 2020; Sammuel, 2018). The revealed evidences have demonstrated a clear signal on the employee's incompetence in implementation of the free and compulsory basic education program in the country. Lack of basic education to children has been among the major problems faced with the Nigerian educational system which requires urgent attention.

Prior studies have postulated that, the attainment of organizational goals largely depends on the level of its employees' competence (Rossilah, 2008). In fact, modern organizations that said to be more successful are gradually realizing that there are pretty number of factors capable of contributing towards increase in employees' competence in organizations. Human resource management practices are seen to be the most essential (Mello, 2005). Thus, work engagement has been regarded as a direct motivational factor capable of ensuring high level of employee competence towards attainment of organizational objectives (Karatepe, 2014).

This paper is an attempt to address the problem since primary education is the foundation to all level of education, a critical to human development and engine for national development (Jennifer, 2018). The paper suggests that, changing the unethical behavior of employees in Nigeria public education system administration, especially UBESA through the help of HRM practice may have important impact on employee's competence and the entire system. Therefore, this paper tends to focus on four aspects of HRM practices (recruitment and selection, training and development, performance appraisal, compensation practices) with mediating role of work engagement within the context of Universal Basic Education system administration in Nigeria.

\section{Research Objectives}

This study aims to examine the mediating role of work engagement in the relationship between HRM practice and employee competence within the context of Nigeria Basic Education system. The main objectives of this study are: 
a. To examine the relationship between human resource management practices (recruitment and selection, training and development, performance appraisal, compensation) and employee competence.

b. To examine the mediating effect of work engagement in the relationship between human resource management practices (recruitment and selection, training and development, performance appraisal, compensation) and employee competence.

\section{Underlying Theories}

Theories are used by researchers especially in quantitative research to answer the research questions (Cresswell, 2014). The main theories used in this research work is the Ability Motivation Opportunity theory and the Social Exchange theory.

\section{Ability Motivation Opportunity Theory}

The present study is based on Lawshe, (1945) AMO view on ability-enhancing practices that are capable of enhancing individual's ability, which in turn lead to achievement of organizational objectives. This theory becomes more appropriate for this study because it has the capacity to explain the complex relationship between how employees are managed and subsequent achievement of organizational goals.

In recent decades, HRM researchers have applied AMO framework to describe HRM practices as factors that influence individual's ability (competencies), which in turn leads to high level of work engagement and attainment of success (Kellner; Townsend, \& Cafferkey, 2019). Employee's competencies, for instance can simply be enhanced through some selected HRM practices (Recruitment and selection, Training and development, performance appraisal, compensation), which can lead to high level of work engagement towards achievement of organizational objectives.

The theory suggests that, the interaction of these elements can help in enhancing individual competence in the quest for achieving organizational goals since it allows different elements to be grouped together (Boselie et al., 2005). In recent times, studies have been conducted to confirm the suitability of applying AMO theory in the field of human resource management. For instance, the study conducted by Marin-Garcia \& Tomas, (2016), Van Waeyenberg \& Decramer, (2018), Ujma \& Igram, (2019). All these studies have confirmed the suitability of applying AMO theory in the field of HRM. Therefore, AMO theory stands as more suitable in explaining the complex relationship between the study variables.

\section{Social Exchange Theory}

The social exchange theory (SET) becomes the main theoretical supporting point for understanding employee's behavior in organizations (DeConinck, 2010). The perspective postulated that when organizations decide to invest in their respective employees, such employees are likely to reciprocate to their organizations in positive manners (Cropanzano \& Mitchell, 2005). The theory depends on two party's relationship. When the first party (UBESA, Management in the current study) practices favorable activities - for example, a better human resource management practices towards the second party (UBESA, employee in the current study). It will motivate the second part which in turn leads to increase in the level of work engagement and subsequently enhances competency in terms of skills, attitudes, knowledge and other social characteristics to reciprocate with the first party (DeConinck, 
2010). Several previous studies have applied social exchange theory in linking human resource management practices (Akhtar et al., 2018; Violetta \& Wechtler, 2018). Based on the above explanation, the mediation role of work engagement on HRM practices and employee competence can be explained by SET. Though, AMO has all the theoretical connection with all the relevant variables. Still, SET can play a supporting role in explaining the research framework.

\section{Literature Review Competence}

Competence has been conceived in relation to job knowledge, attitudes and skills (Tao et al., 2016). Parry, (1996) sees competency as a collection of work-related skills, attitude and knowledge. Likewise, it's also consist of the fundamental aspect of an individual which entails job knowledge, skills as well as attitudes which empowers to be more competent (Han et al., 2006; Moore et al., 2002). It has become imperative to stress the indispensable values of competency, since competencies are most widely used in modern organizations and different aspect of human resource management studies. In addition, employee competence has been suggested by literature as one of the important factors that tends to contribute greatly towards ensuring organizational excellence (Cummings \& Worley, 2001; Vathanophas, 2007).

\section{Human Resource Management Practices}

Human resource management practices consist of recruitment and selection, training and development, planning, compensation practices, performance appraisal, among others which can enhance employee competence and be source of competitive advantage in achievement of organizational objectives (Boxall, 2003; Paauwe \& Boselie, 2005). Human resource management is a term that refers to those activities taken in an organization that are solely concern with the management and the development of employees through its practices (Wall \& Wood, 2005). In this study, four aspects of HRM practices (Recruitment and Selection, Training and Development, Performance Appraisal, Compensation) are considered as independent variables in the relationship with employee competence.

\section{Relationship Between Recruitment and Selection and Employee Competence}

Recruitment and selection are been regarded as skill and ability enhancing human resource practices (Subramony, 2009). Attracting suitable applicants that possesses the required knowledge, ability and skills is an undisputable method typically used in encouraging the vision of both skill acquisition and skill development in contemporary firms (Subramony, 2009). Several empirical studies revealed that proper recruitment and selection can lead to the increase in employee's competence. For instance, the study conducted by Otoo, (2018) to investigate the influence of HRM practices on employee competencies using 500 sample size from banking industry in Ghana, the result shows a significance connection between recruitment and selection practice and employee's competence. Another study was also conducted in recent times by Alshibli, (2019) in an attempt to explore the impact of HRM practices in Jodanian private universities and sample size consisting of 104 employees was utilized, the result also reveals a positive relationship between recruitment and selection and employee's competence. 


\section{Relationship Between Training and Development and Employee Competence}

Training and development can be defined as indispensable element, most of which countries used in developing the intellectual and skills of its workforce towards attainment of organizational great performance and success (Jauhar et al., 2015). Training and development are viewed among the most extensive and wide spread human resource management practices (Boselie et al., 2005). Several empirical studies have been conducted in the quest to examine the relationship between training and development and employee competence. For instance, a study carried out by Mahmood et al., (2018) in investigating the relationship between training and employee performance with employee competence as mediator, the study reveals a positive relationship between training and employee's competence. This was supported by the study conducted to examine the influence of human resource management practices and employee competence in a Ghanian Banking industry with 500 employees as sample size and the result indicated a significant relationship between training and development and employee competence.

\section{Relationship Between Performance Appraisal and Employee Competence}

Performance appraisal is demonstrating much relevance in the achievement of organizational objectives since organizational success is gradually becoming explicit through enumeration and quantification and firms' objectives are always set based on performance appraisal in human resource management practices (Sabi'u, 2017). Many empirical studies have been conducted in the quest to examine the existing relationship between performance appraisal and employee competence. For instance, the study that was carried out by Islam \& Siengthai, (2010) in an export processing company of Bangladesh with a sample of 53 enterprises consisting of 216 respondents which the findings indicates a positive relations between performance appraisal and employee competence. In recent times, another study was also undertaken by Alshibli, (2019) to investigate the influence of selective human resource management practices and employee competence in the context of Jordan private universities using 104 employees as the respondents, the result also indicated a significant relationship between the practice of performance appraisal and employee competence.

\section{Relationship Between Compensation and Employee Competence}

Compensation practice differ expressively across organizations and across jobs in some situations. It brings out employee job satisfaction, ensures motivation, low turnover and low absenteeism as well as provides adequate rewards in exchange to employee's service delivery (Quartey \& Attiogbe, 2013). The main aim of compensation bundle as HRM practice is to ensure increase in employee competence and job satisfaction towards discharging their responsibilities and improve in organizational performance (Joarder \& Ashraf, 2012; Rodrigues \& Pinho, 2010; Yousef, 2000). Numerous empirical researches have been conducted to investigate the relationship between compensation and employee competence. For example, the study conducted by (Thang, 2004) reveals a positive relationship between compensation and employee competency. In the same vein, a study was also conducted by Nana \& Otoo, (2018) in an Indian hotel industry with 700 employees as sample size in determining the mediating effect of employee competence in a relationship between HRM practices and performance of industry, the findings also shows a significant connection between compensation and employee's competence. Based on the reviewed literature, the current study proposes the following hypothesis; 
H1: Recruitment and Selection significantly relates to employee competence

H2: Training and Development positively relates to employee competence

H3: Performance Appraisal positively relates to employee competence

H4: Compensation significantly relates to employee competence

Based on the above argument, this study suggests that when Nigerian UBESA adopt a better means of recruitment and selection by selecting employees based on merit, providing them with adequate training and retraining towards developing their competence in ensuring the attainment of organizational success, introduce an effective performance appraisal system that will enhance employee competence and performance and provide them with excellent compensation as reward for high performance, these will lead to the achievement of organizational objectives.

\section{Relationship Between Work Engagement and Employee Competence}

Work engagement can be seen as the degree to which employees in an organization relate to their jobs and other responsibilities as part of their entire life. Work engagement has also been seen with critical essentials such like energy, work focus and absorption in work (Schaufeli et al., 2002). Prior empirical studies have revealed the vital role of work engagement in enhancing employee competence in different context. For instance, Seema, (2016) in her study on the influence of managerial competencies on work engagement in an Indian IT sector, revealed a significant relationship between work engagement and managerial competencies. Similarly, another study was conducted by Nawangsari \& Sutawidjaya, (2019) with a sample of 101 employees from a small and medium enterprise located in Malang, Indonesia. The result revealed a positive relationship between employee engagement and competencies. Accordingly, the present study hypothesized that:

H5: Work Engagement positively related to Employee Competence.

\section{Mediating Role Of Work Engagement}

Work engagement is regarded as a productive and substantial work-related disposition essentially characterized by vigor, absorption and dedication (Schaufeli et al., 2002). Vigor is perceived as energy and high rate of mental resilience in handling organizational responsibilities, dedication is considered as a sense of pride, significance and enthusiasm, while absorption is seen as entirely being focused and readiness to involve in other persons task (Karatepe \& Olugbade, 2009). Work engagement is being considered as an end result or an effect of human resource management practices (Aktar \& Pangil, 2018; Karatepe, 2013; Saks, 2006), work engagement appeared to be a direct motivational factor in enhancing employee competence as suggested by Karatepe, (2014). Yet, research that investigate the mediating role of work engagement in the relationship between HRM practices and employee competence appears to be scarce in the existing literature. Based on this, the current study employed work engagement to mediate on the relationship between the selected HRM practices and employee competence.

Prior empirical studies have confirmed the suitability of mediating role of work engagement in explaining the complex relationship between two variables (independent and dependent). For instance, Karatepe, (2013), conducted a study in Romanian hotel industry using 123 employees as sample to investigate the mediating effect of work engagement in the relationship between HRM practices and performance of employees. The study reveals that, 
work engagement plays a full role as mediator in explaining the relationship between high performance work practices and employee performance. Other studies includes the study conducted by Trong, (2018) in examining the mediation effect of employee engagement in the relationship between service oriented high performance work practices and service oriented behavior in Vietnam public legal firms using 100 employees as sample size. The result shows a strong mediating effect of work engagement in the relationship between high performance work practices and service-oriented behavior. Recently, another study was conducted by Aboramadan et al., (2020) in Palestinian universities using 237 employees as sample size in examining the effect of work engagement as a mediator in a relationship between human resource management practices and organizational commitment. Based on the above-mentioned empirical evidences. The current study hypothesized that:

H6: WE mediate the relationship between the selected HRM practices and employee competence

Findings of this study will provide a clear empirical explanation on how the combination of these HRM practices (recruitment and selection, training and development, performance appraisal, compensation) can address employee's incompetency in UBESA towards the implementation of the free and compulsory basic education through work engagement. Employee competence have been seen as a vital instrument that contribute most in the attainment of organizational objectives (Vathanophas, 2007).

\section{Research Framework}

In the reviewed literature, it has been clearly confirmed that there is a significant relationship between HRM practices and employee competence. Existing literature has also confirmed the significant influence of work engagement in explaining the existing relationship between two variables (dependent and independent variables). Findings from these studies have been generalized mostly based on samples from manufacturing, banking, hospitality, hotel and other private sectors in Asian and western context without taking the Sub-Sahara Africa and Nigerian Universal Basic Education System Administration into consideration. Studies that tend to examine the mediating role of work engagement in the relationship between HRM practices and employee competence in one model appears to be scarce in the existing literature. This paper proposed the following conceptual framework:

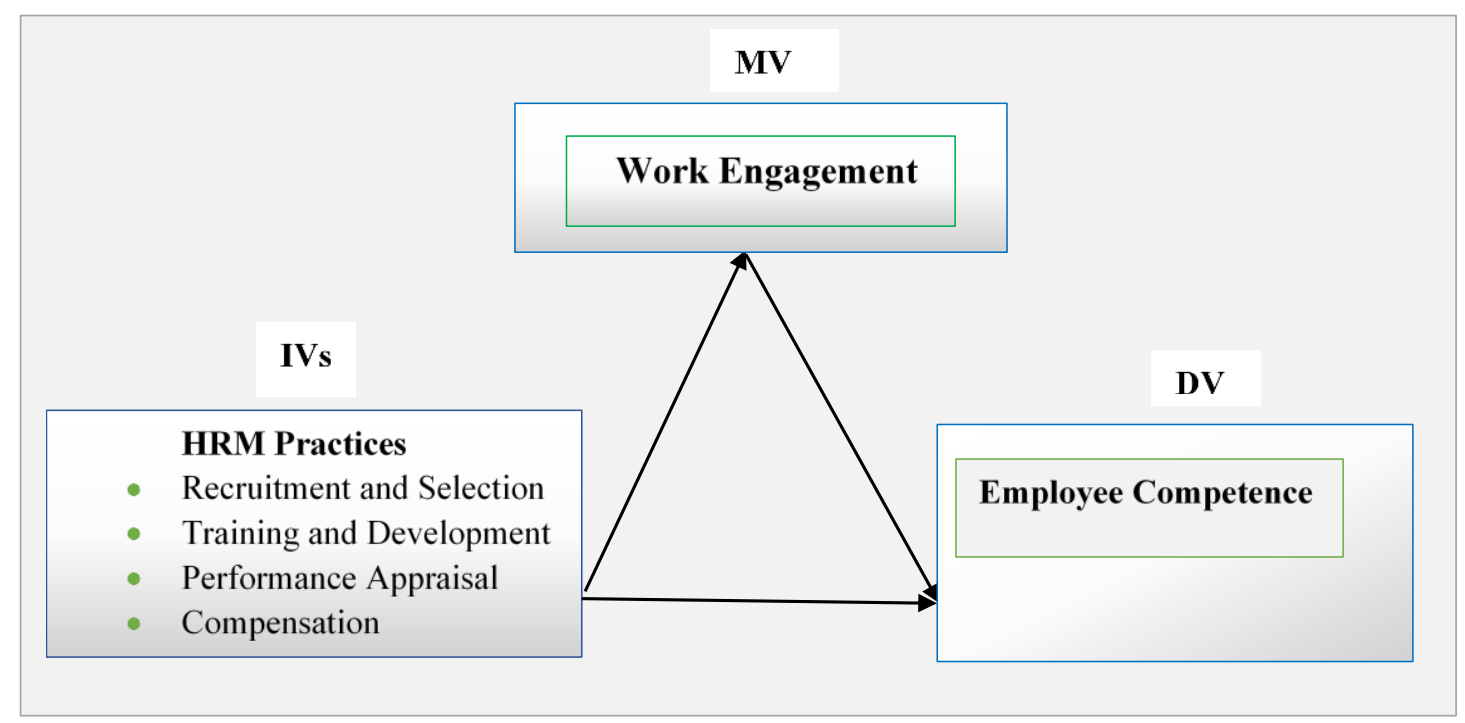

Figure 1. Proposed Conceptual Framework of the study 


\section{Methodology}

\section{Procedures and Respondents}

The current study targeted the non-managerial category of employees in UBESA across seven states (Kano, Kaduna, Katsina, Kebbi, Sokoto, Jigawa and Zanfara State) of the North Western zone of Nigeria. This category of employees is chosen to represent the entire organizations because they are placed at the implementation level (under social and mobilization department) saddled with the responsibility of ensuring strict compliance by parents of the affected group through the departmental activities such like advocacy and sensitization, community empowerment and other activities that aid to cater for learning needs for the beneficiaries across the various states of the federation. The total population is 24,265 . In this study, Kebbi state is excluded from the sample population for the purpose of pilot study because of its limited number of employees (2353). The targeted population for this study is $21,913(24,265-2353)$ in the six states.

The proportionate stratified sampling is considered as appropriate technique for the purpose of this study in ensuring adequate representation. In the quest to attain the goals of this research work, the respondents will be grouped into stratums for six UBESA. Then, after stratifying the respondents into six strata, then number of respondents will be determined from each stratum to represent total population. The study chooses seven North Western states UBESA as unit of analysis to represent the entire Nigeria UBESA, because it is the most affected zone with $60 \%$ of the total number $(10.5 \mathrm{~m})$ of out-of-school children in Nigeria (UNICEF, 2018), they share the same ethics, rules and condition of service and constitute $40 \%$ of the total Nigerian population (Ademolekun, 2013). Again, the Northern zone has the highest rate of poverty constituting $87 \%$ of the poverty rate in the country (World Bank, 2020).

\section{Measures}

The first aspect of the instruments covers HRM practices (recruitment and selection, training and development, performance appraisal, compensation). Recruitment and selection was assessed using a scale of eight (8) items by previous studies (Amin et al., 2014; Delaney \& Huselid, 1996; Pfeffer, 1998; Sabi'u, 2017; Terpstra \& Rozell, 1993). Training and development is assessed using a scale of seven (7) items tested in previous studies (Arthur, 1994; Macduffie, 1995; Pfeffer, 1998; Sabi'u, 2017). Performance appraisal measured by six (6) items tested in previous studies (Delaney \& Huselid, 1996; Delery \& Doty, 1996; Sabi'u, 2017; Snell \& Dean, 1992; Youndt et al., 1996). Compensation practice is measured through five (5) items tested in previous studies (Arthur, 1994; Delaney \& Huselid, 1996; Delery \& Doty, 1996; Sabi'u, 2017).

The second aspect of the instruments covers work engagement. The instrument is measured based on shorten version of Utrecht work engagement scale which was validated by Schaufeli, et al., (2002), through seventeen (17) items. While the third aspect covers employee competence. The instrument is measured based on twenty-six (26) items. These items were developed and tested by previous studies.(Hellriegel \& Slocum, 2011) employee competency scale, Eby \& Dobbins (1997) team work scale, Wiemann, (1977) communication competency scale, Rest, (1994) competent model, Kavathatzopoulos et al., (2008) ethical competence scale. These items are adapted with some modifications to suit the current study. The items 
will be measured based on 10-point Likert scale since it has been considered as more suitable (Awang, 2015).

\section{Pretest and Pilot Test}

The content validity of the instruments intends to use for the purpose of this study have been confirmed through experts' comments from the academia and industry. Experts in the relevant field of study were carefully identified before sending the instruments to them soliciting for their comments related to HRM practices, work engagement and employee competence. A pilot test will be administered to 100 employees working with Kebbi State UBESA, who are not part of the actual study sample to ensure the construct validity before the actual data collection. The Cronbach's alpha will be utilized in determining whether all the items are measuring the same thing in the test, because of its wider coverage (Ary et al., 2012).

\section{Statistical Analysis}

The study employs the use of Statistical Package for Social Science (SPSS) for the descriptive and inferential statistics. The Exploratory Factor Analysis (EFA) will also be performed using SPSS with the data obtained from the pilot test which will subsequently be used for the main study so as to identify the underlying factor structure of the data and also test the reliability of the research tool. while Structural Equation Modeling (SEM-AMOS) will be used for the confirmatory factor analysis in assessing the validity and reliability of the constructs, fitness indexes and normality for the measurement model. For the purpose of determining the structural model, the mediation analysis will be performed as well as bootstrapping method in confirming the mediation result using SEM.

\section{Conclusion}

The conceptual study will clearly proffer explanation on the effect of work engagement in the relationship between human resource management practices and employee competence within the context of the Universal Basic Education System Administration in Nigeria. Basic education (primary education) is the foundation to all levels of education and can also serve as engine for national growth and development. Therefore, the unique findings of this study will significantly contribute to the existing literature both theoretically and practically.

Theoretically, the study will be important since research on the mediating role of work engagement in the relationship between human resource management practices and employee competence seem to be scarce in the existing literature and most of the related studies were conducted based on private sector organizations in Western and Asian context without taking other continent like Sub-Sahara Africa into consideration. While this study focused on public sector organization (UBESA) Nigeria in particular as recommended by Sabi'u, (2017).

The study will contribute immensely to the growing number of literatures especially in the field of human resource management, organizational behavior and other related field of study. Moreover, public sector organizations remain the highest employers of labor containing more employees than the private sector organizations (Sanusi \& Martadha, 2012). Similarly, the study will provide empirical evidence on the mediating effect of work engagement on the relationship between four aspects of HRM practices (recruitment and 
selection, training and development, performance appraisal, compensation) and employee competence in Nigerian UBESA which is yet to be explore in the literature.

Practically, this study will be very important to the public educational sector organizations and other related parastatal/agencies in providing them with some useful guides on how to improve employee's competence from the current situation and move towards increased effectiveness and efficiency in implementing governmental policies and programs especially the educational policies to enable them compete with other developed nations in the world. Similarly, findings of the current study will also serve significantly as a guide and mechanism for policy makers, human resource management expertise and other related fields. Therefore, the study will provide a clear empirical explanation on how the combination of four HRM practices can address the employee's incompetency in UBESA towards the implementation of the free and compulsory basic education through work engagement.

\section{References}

Aboramadan, M., Belal, A., \& D., K. A. (2020). Human resources management practices and organizational commitment in higher education The mediating role of work engagement. International Journal of Educational Management, 34(1), 154-174. https://doi.org/10.1108/IJEM-04-2019-0160

Ademolekun, L. (2013). Education Sector in Crisis: Evidence, Causes and Possible Remedies. Being a Paper Presented at the 2012/2013 Distinguished Lecture of Joseph Ayo Babalola University (JABU), Ikeja Arakeji, Osun State. Thursday, January, 24.

Akhtar, M. N., Long, L., \& Zhang, Y. (2018). High-performance work system and employee performance : the mediating roles of social exchange and thriving and the moderating effect of employee proactive personality. July. https://doi.org/10.1111/17447941.12199

Aktar, A., \& Pangil, F. (2018). "Mediating role of organizational commitment in the relationship between human resource management practices and employee engagement: Does black box stage exist?" International Journal of Sociology and Social Policy, 38(7), 606-636. https://doi.org/10.1108/IJSSP-08-2017-0097

Al-Ansari, Y., Xu, J., \& Pervan, S. (2014). A study of organisational determinants and innovation practices in Dubai SMEs. International Journal of Innovation Management, 18(1), 1450003 (28 pp.). http://doi.org/10.1142/S1363919614500030

Al-Dhaafri, H. S., Al-Swidi, A. K., \& Yusoff, R. Z. (2016). The mediating role of total quality management between the entrepreneurial orientation and the organizational performance. The TQM Journal, 28(1), 89-111.

http://doi.org/10.1177/0266242610391930

Alshibli, A. S. (2019). The Impact of Selective Human Resources Management Practices on the E mployee 's Competences at Jordanian Private Universities . Case Study on Applied Science, Philadelphia, and Al-zaytoneh Universities. IUG Journal of Economics and Business, 27(1), 20-41.

https://journals.iugaza.edu.ps/index.php/IUGJEB/article/download/5021/2377

Amin, W., Ismail, W. K. W., \& Rasid, S. Z. A. (2014). The Impact of Human Resources Management Practices on Performance: Evidence from a Public University. The TQM Journal, 26(2), 125-142. https://doi.org/http://doi.org/10.1108/TQM-10-2011-0062

Aminu, W. (2015). Sokoto to declare state of emergency in education sector. The Gardian, 12. https://guardian.ng/news/sokoto-state-to-declare-state-of-emergency-in-education- 
sector/

Anthony, A. (2020). ICPC traces N2.67bn school feeding funds to private accounts. Business Day, 1-2. https://businessday.ng/news/article/icpc-traces-n2-67bn-school-feedingfunds-to-private-accounts/

Armstrong, E. (2005). Integrity, transparency and accountability in public administration: Recent trends, regional and international developments and emerging issues. United Nations, Department of Economic and Social, 1-16. https://www.researchgate.net/publication/265064749_Integrity_Transparency_and_A ccountability_in_Public_Administration_Recent_Trends_Regional_and_International_D evelopments_and_Emerging_Issues

Arthur, J. B. B. (1994). "Effect of Human Resource systems on manufacturing performance and turnover." Academy of Management Journal, 37(3), 670-687. https://doi.org/http://doi.org/10.2307/256705

Ary, D., Jacobs, L. C., \& Sorensen, C. (2012). Introduction to Research in Education (8th ed.). Australia: Wadsworth.

Awang, Z. (2015). SEM MADE SIMPLE: A Gentle to Learning Structural Equation Modelling. NPWS Rich Publication Sdn. Bhd. (1132290-K).

Boselie, J. P., Dietz, G., \& Boon, C. (2005). Commonalities and contradictions in research on human resource management and performance. Human Resource Management Journal, 15(3), 67-94. https://doi.org/10.1111/j.1748-8583.2005.tb00154.x

Boxall, P. (2003). HR strategy and competitive advantage in the service sector. Human Resource Management Journal, 13(3), 5-20. https://doi.org/http://doi.org/10.1111/j.1748-8583.2003.tb00095.x

Claudia, I. (2017). Universal Basic Education in Nigeria. Centre for Public Impact. https://www.centreforpublicimpact.org/case-study/universal-basic-education-nigeria/

Cresswell, J. W. (2014). Research Design: Qualitative, Quantitative and Mixed methods $\begin{array}{lllll}\text { approaches. } & \text { (4th } & \text { ed.). }\end{array}$ https://doi.org/http://doi.org/10.2307/3152153

Cropanzano, R., \& Mitchell, M. S. (2005). Social exchange theory: An Interdisciplinary review. Journal of Management, 31(6), 874-900. https://doi.org/10.1177/0149206305279602

Cummings, T., \& Worley, C. (2001). Organization development and change. Mason, Ohio: South: Western College Publishing. International Journal of Engineering and Social Science.

Darwish, S., Abdo, H., \& AlShuwaiee, W. M. (2018). Opportunities, challenges and risks of transition into renewable energy: the case of the Arab Gulf Cooperation

Council. International Energy Journal, 18(4).

DeConinck, J. B. (2010). The effect of organizational justice, perceived organizational support, and perceived supervisor support on marketing employees' level of trust. Journal of Business Research, 63(12), 1349-1355. https://doi.org/10.1016/j.jbusres.2010.01.003

Delaney, J. T., \& Huselid, M. A. (1996). The Impact of Human Resource Management Practices on Perceptions of organizational Performance. Academy of Management Journal, 39(4), 949-969. https://doi.org/http://doi.org/10.2307/256718

Delery, J. E., \& Doty, D. H. (1996). Modes of Theorizing in Strategic Human Resource Management: Test of Universalistic, Contingency, and Configurational Performance Predictions. Academy of Management Journal, 39(4), 802-835. http://doi.org/10.2307/256713

Eby, L. T., \& Dobbins, G. H. (1997). Collective orientation in teams: an individual and group- 
level analysis. Journal of Organizational Behavior, 18, 275-295.

Ezeamalu, B. (2015). For the Records: President Muhammadu Buhari's 2015 Inaugural Speech. Premium Times, 1-7. https://www.premiumtimesng.com/features-andinterviews/183975-for-the-records-president-muhammadu-buharis-2015-inauguralspeech.html

Han, J., Chou, P., Chao, M., \& Wright, P. M. (2006). The HR competencies HR effectiveness link: A study in Taiwanese high tech companies. Human Resource Management, 45(3), 391-406.

Hellriegel, D., \& Slocum, J. W. J. (2011). Organizational Behavior, Southwest Cengage Learning (13th ed.). Mason, OH : South-Western Cengage Learning, (C2011. https://www.worldcat.org/title/organizational-behavior/oclc/430053363

Inyang, B. J., \& Akaegbu, J. B. (2014). Redefining the Role of the Human Resource Professional (HRP) in the Nigerian Public Service for Enhanced Performance. International Journal of Business Administration, 5(1), 90-98.

https://doi.org/http://doi.org/10.5430/ijba.v5n1p90

Jauhar, J., Ghani, A. B. A., Joarder, M. H. R., Subhan, M., \& Islam, R. (2015). Brain drain to Singapore: A conceptual framework of Malaysians' diaspora. The Social Sciences, 10(6), 702-711. https://medwelljournals.com/abstract/?doi=sscience.2015.702.711

Jennifer, V. (2018, February). Nigeria Comes Face to Face with a Huge Literacy Crisis. Proliteracy; Proliteracy. https://proliteracy.org/Blogs/Article/311/Nigeria-Comes-Faceto-Face-with-a-HUGE-Literacy-Crisis\#

Joarder, M. H. R., \& Ashraf, M. A. (2012). Work Satisfaction and Employee Turnover Intentions: An Empirical Study. East West Journal of Business \& Social Studies, 3(1), 18 36. http://www.ewubd.edu/ewu/showDocument.php?documentid=1285

Karatepe, O. (2013). International Journal of Hospitality Management High-performance work practices and hotel employee performance : The mediation of work engagement. International Journal of Hospitality Management, 32, 132-140. https://doi.org/10.1016/j.ijhm.2012.05.003

Karatepe, O. M. (2014). Hope, Work Engagement, and Organizationally Valued Performance Outcomes: An Empirical Study in the Hotel Industry. Journal of Hospitality Marketing \& Management, 23(6), 678-698. https://doi.org/10.1080/19368623.2014.855994

Karatepe, O. M., \& Olugbade, O. . (2009). The effects of job and personal resources on hotel employees' work engagement. International Journal of Hospitality Man-Agement, 28(4), 504-512.

Kavathatzopoulos, I., Kostrzewa, A., \& Berg, A. (2012). Measuring ethical competence of organizations. Journal of Business Ethics, 1-17. http://www.it.uu.se/research/project/ethcomp/Kavathatzopoulos_et_al._Measuring_e thical_competence_of_organizations_081014-1.pdf

Kellner, A. K., Townsend, K., \& Cafferkey, K. (2019). "Ability Motivation and Opportunity Theory: A Formular for Employee Performance?" In T. Keith, C. Kenneth, M. Mcd. Aoife, \& D. Tony (Eds.), Elgar Introduction to theories of Human Resources and Employment Relations (pp. 311-323). Edward Elgar Publishing Limited.

Lawshe. (1945). Elgar Introduction to Theories of Human Resources and Employment Relations. (T. Keith, C. Kenneth, A. M. MC Dermott, \& D. Tony (eds.)). Edward Elgar Publishing Limited. https://doi.org/DOI 10.4337/9781786439017

Lo, F. Y., \& Fu, P. H. (2016). The interaction of chief executive officer and top management team on organization performance. Ournal of Business Research, 69(6), 2182-2186. 
http://doi.org/10.1016/j.jbusres.2015.12.027

Macduffie, J. P. (1995). Human Resource bundle and manufacturing performance: Organizational logic and flexible production systems in the wold auto industry. Industrial \& Labor Relations Review, 48(2), 197-221. https://doi.org/http://doi.org/10.2307/2524483

Mahmood, A., Khurshid, M. K., Bashir, M., \& Sabir, H. M. (2016). The Impact of High Performance Work System On Employee Attitude: The Mediating Role of Human Resource Flexibility. 28(4), 61-68.

Marin-Garcia, J. A., \& Tomas, J. M. (2016). Deconstructing AMO framework: A systematic review. Intangible Capital, 12(4), 1040-1087. https://doi.org/10.3926/ic.838

Mello. (2005). Strategic Human Resource Management (2nd ed.). South-Western.

Moore, D. R., Cheng, M. I., \& Dainty, A. R. J. (2002). Competence and competencies: performance assessment in organisations. Work Study, 51(6), 314-319.

Nana, F., \& Otoo, K. (2018). Impact of Human Resource Management ( HRM ) Practices on Hotel Industry's Performance : The Mediating role of Employee Competencies. IX(2), 1730. https://doi.org/10.18843/ijcms/v9i2/03

Nasiru, E.-R. (2015, October). El-Rufa'i Declares State Of Emergency In Kaduna State Education Sector. The Herald, 1-2. https://www.herald.ng/el-rufai-declares-state-of-emergencyin-kaduna-state-education-sector/

Nawangsari, L. C., \& Sutawidjaya, A. H. (2019). Talent Management in Mediating Competencies and Motivation to Improve Employee's Engagement. International Journal of Economics and Business Administration, VII(1), 140-152. https://www.ijeba.com/journal/201/download

Ngige, C. (2020). Nigeria's Unemployment rate hits 33.5 percent by 2020 - Minister. Premium Times, 1-2. https://www.premiumtimesng.com/news/top-news/328137-nigeriasunemployment-rate-hits-33-5-per-cent-by-2020-minister.html

Otoo, F. N. K. (2018). Impact of Human Resource Development Practices on Employee Competencies. International Journal of Management Studies, V(3(2)), 116. https://doi.org/10.18843/ijms/v5i3(2)/15

Paauwe, J., \& Boselie, P. (2005). HRM and performance: What next? Human Resource Management Journal, 15(4), 68-82. https://doi.org/DOI: 10.1111/j.17488583.2005.tb00296.x

Parry, S. B. (1996). Just What Is a Competency?(And Why Should You Care?). ERIC Journal, 35(6), 58-60, 62, 64. https://eric.ed.gov/?q=Just+What+ls+a+Competency\%3F(And+Why+Should+You+Care \%3F).\&id=EJ566039

Pfeffer, J. (1998). Seven practices of successful organizations. California Management Review, 4O(2), 96-123. https://doi.org/DOI: 10.2307/41165935

Quartey, S. H., \& Attiogbe, E. J. (2013). Is there a link between compensation packages and job performance in the Ghana police service? 7(44), 4398-4406. https://doi.org/http://doi.org/10.5897/AJBM2013.7201

Rastgoo, P. (2016). The role of human resources competency in improving the manager performance. Acta Universitatis Agriculturae et Silviculturae Mendelianae Brunensis, 64(1), 341-350. https://doi.org/10.11118/actaun201664010341

Rest, J. R. (1994). Background: Theory and research. In Rest, J. R. and Narvaez, D. (Eds.), Moral development in the professions: Psychology and applied ethics.

Rodrigues, A. P., \& Pinho, J. C. M. R. (2010). Market orientation, job satisfaction, commitment 
and organisational performance: The specific case of local public sector. Transforming Government: People, Process and Policy, 4(2), 172-192. http://doi.org/10.1108/17506161011047398

Rossilah, J. (2008). Analisis Kepeluan Latihan Teori dan Praktis, Edisi Pertama,. Universiti Teknologi Malaysia.

Sabi'u, S. (2017). Relationship Between Aspect of Human Resource Management Practices and Organizational Performance: Mediating Role of Ethical Climate [University Utara Malaysia]. 900159.

Saks, A. M. (2006). "Antecedents and Consequences of employee engagement." Journal of Managerial Psychology, 21(7), 600-619.

Sammuel, G. O. (2018). How Corruption is Affecting Basic Education in Nigeria. International Anti-Corruption Conference. https://iaccseries.org/blog/how-corruption-is-affectingbasic-education-in-nigeria/

Sanusi, A., \& Martadha, A. M. (2012). Good Governance as a Yardstick to Measure the Effectiveness of E-recruitment in Nigerian Public Service. Journal of US-China Public Administration, 9(1), 1-7.

Sargit, S., Nobaya, A., \& Babei, H. (2012). Bonding, Bridging and Linking Social Capital and Psychological Empowerment Among Squatter Settlement in Tehran, Iran. Journal of Basic and Applied Scientifi c Research, 2(3), 26-50.

Schaufeli, W. B., Salanova, M., González-Romá, V., \& Bakker, A. B. (2002). "The measurement of engagement and burnout: a two sample confirmatory factor analytic approach". Journal of Happiness Studies, 3(1), 71-92.

Schaufeli, W., Salanova, M., \& Gonzalez-Roma, B. A. (2002). The measurement of engagement and burnout: a two sample confirmatory factor analytical approach. Journal of Happiness Studies, 3, 71-92.

SDG. (2018). New education data for SDG4: Focus on out-of-school children, 27 September 2018. https://www.sdg4education2030.org/new-education-data-sdg4-focus-outschool-children-27-september-2018

Seema. (2016). The Effect of Managerial Competencies on Employee Engagement in Multinational IT Industries. International Journal of Latest Trends in Engineering and Technology, 7(3), 28-34. https://doi.org/DOI: http://dx.doi.org/10.21172/1.73.504

Snell, S. A., \& Dean, J. W. (1992). Intergreted Manufacturing and Human Resource Management: A Human Capital Perspective. Academy of Management Journal, 35(3), 467-504. https://doi.org/http://doi.org/10.2307/256484

Speklé, R. F., \& Verbeeten, F. H. M. (2014). The use of performance measurement systems in the public sector: Effects on performance. Management Accounting Research, 25(2), 131-146. https://doi.org/10.1016/j.mar.2013.07.004

Subramony, M. (2009). A meta-analytic investigation of the relationship between HRM bundles and firm performance. Human Resource Management, 48(5), 745-768. https://doi.org/10.1002/hrm.20315

Tao, Y. H., Yeh, C. R., \& Sun, S. I. (2016). Improving training needs assessment processes via the Internet: system design and qualitative study. Internet Research, 16(4), 427-449.

Terpstra, D. E., \& Rozell, E. J. (1993). The Relationship of Staffing Practices to Organizational Level Measures of Performance. Personnel Psychology, 46(1), 27-48. https://doi.org/http://doi.org/10.1111/j.1744-6570.1993.tb00866.x

Thang, L. (2004). Managing Human Resources in Vietnam: An empirical study of an economy in transition. [Asian Institute of Technology, Thailand.]. Doctoral Dissertation. 
Trong, L. T. (2018). Service-oriented high-performance work systems and service-oriented behaviours in public organizations: the mediating role of work engagement. Public Management Review, 21(1), 1-28. https://doi.org/10.1080/14719037.2018.1526314

UBE Act, 2004, Pub. L. No. 2 (1), 113 (2004). http://nigeriaeducation.org/literature/compulsory-free-universal-basic-education-act-2004

Ujma, M., \& Igram, T. (2019). Perception of ability-motivation-opportunity oriented HRM practices and organizational commitment: The role of task uncertainty. Journal of Entrepreneurship, Management and Innovation, 1(50), 40-287. https://doi.org/DOI: https://doi.org/10.7341/20191545

UNICEF. (2018). Nigeria Has the Highest Number of Out-of-school Children in the World. Cision PRWeb. https://www.prweb.com/releases/2018/04/prweb15403959.htm

Van Waeyenberg, T., \& Decramer, A. (2018). Line managers' AMO to manage employees' performance: The route to effective and satisfying performance management. The International Journal of Human Resource Management, 29(22). https://doi.org/https://doi.org/10.1080/09585192.2018.1445656

Vathanophas, V. (2007). Competency requirements for effective job performance in the Thai public sector. Contemporary Management Research, 3(1), 45-70.

Violetta, K., \& Wechtler, H. (2018). HR practices and employee performance: the mediating role of well-being. Employee Relations, 40(1), 227-243. https://doi.org/10.1108/ER-082017-0191

Wall, T. D., \& Wood, S. J. (2005). The romance of human resource management and business performance, and the case for big science. In Human Relations (Vol. 58, Issue 4). https://doi.org/10.1177/0018726705055032

Wang, N., Cao, J., \& Ye, X. (2016). The impact of intellectual capital - knowledge management strategy fit on firm performance. Management Decision. http://doi.org/10.1108/MD-062015-0231

Wiemann, J. M. (1977). Explication and Test of a Model of Communicative competence. Human Communication Research, 3(3), 195-213.

World Bank. (2014). Out-of-school children: a promise yet to be fulfilled. https://blogs.worldbank.org/education/out-school-children-promise-yet-be-fulfilled

WorldBank. (2020). Worl Bank: Eighty Seven Percent of Poor Nigerians Are Northerners. The Cabal. https://www.thecable.ng/world-bank-north-accounts-87-poor-people-nigeria

Youndt, M. A., Snell, S. A., Dean, J. J. W., \& Lepak, D. P. (1996). Human Resource Manageent, Manufacturing Strategy, anf Firm Performance. Academy of Management Journal, 39(4), 836-866. https://doi.org/http://doi.org/10.2307/256714

Yousef, D. A. (2000). Organizational commitment: a mediator of the relationship behavior with job satisfaction and performance in a non-western country. Journal of Managerial Psychology, 15(1), 6-28. http://doi.org/10.1108/02656710210415703 